\title{
Taura syndrome of penaeid shrimp: cloning of viral genome fragments and development of specific gene probes
}

\author{
Jocelyne Mari $^{1}$, Jean-Robert Bonami ${ }^{2, *}$, Donald V. Lightner ${ }^{1}$ \\ ${ }^{1}$ Department of Veterinary Science, University of Arizona, Tucson, Arizona 85721, USA \\ ${ }^{2}$ UMR2 19, CNRS-IFREMER, Université Montpellier II, Place E. Bataillon, F-34095 Montpellier Cedex 5, France
}

\begin{abstract}
The ssRNA genome extracted from purified Taura Syndrome Virus (TSV) was transcribed into double-stranded, blunt-ended cDNA and was used to construct cDNA libraries either in pUC 18 or in pBluescript II KS-vectors. Twelve recombinant plasmids chosen after screening of the libraries were subjected to restriction enzyme digestions for determination of size inserts and restriction maps. Two of them, pP15 and pQ1, were selected for probe construction. The inserts, 1500 and 1300 base pairs (bp) respectively, were DIG-11dUTP-labelled and the corresponding probes were named P15 and Q1 On northern blots and dot blots, using different denaturation methods, the 2 probes hybridized specifically with extracted RNA-TSV genome, TSV and infected TS shrimp homogenates. No positive hybridization was obtained with other shrimp viruses tested [Infectious Hypodermal and Hematopoietic Necrosis Virus (IHHNV) and Hepatopancreatic Parvovirus (HPV)]. The specificity of the 2 probes was confirmed by in situ hybridization on histological sections of TS diseased shrimps.
\end{abstract}

KEY WORDS: TSV · Penaeid shrimp Picomavirus $\cdot$ Cloning $\cdot$ Dot blot hybridization $\cdot$ In situ hybridization

\section{INTRODUCTION}

Taura syndrome (TS) of penaeids was first recognized in shrimp farms located on the Taura river in Ecuador (Jimenez 1992) and initially attributed to toxicity of a fungicide used in banana plantations adjacent to affected shrimp farms (Jimenez 1992, Lightner et al. 1994, Wigglesworth 1994). Further investigation demonstrated that the suspected fungicides involved did not induce the histological lesions characteristic of the disease, which are necrosis and nuclear pyknosis of the cuticular epithelium of the general body surface, appendages, gills, mouth, esophagus, stomach and hindgut (Brock et al. 1995, Lightner et al. 1995, Lightner 1996b). Transmission electron microscopy studies of infected TS shrimps demonstrated the presence of putative cytoplasmic virus particles named TSV (Brock et al. 1995). The viral etiology of the TS was demon-

\footnotetext{
•E-mail: bonami@crit.univ-montp2.fr
}

strated by Hasson et al. (1995). Recently the virus was characterized as a probable member of the Picornaviridae (Bonami et al. 1997).

Since its discovery in 1992 in Ecuador, the geographical distribution of TS has dramatically expanded throughout the Americas (Lightner 1996a). This disease represents a serious problem in the culture of Penaeus vannamei due to the high level of mortality and the economic losses induced. No prophylactic treatment is available and the diagnosis of TS is routinely made by examining diseased animals using histological methods (Lightner et al. 1995, Lightner 1996b).

To better understand, control and prevent the spread of TS, more sensitive diagnostic tools such as monoclonal antibodies or gene probes will be necessary to investigate the host range of the TSV, its transmission, and to permit the detection of the early stages of the infection. The use of gene probes in disease diagnosis and investigations was developed for other shrimp virus diseases (Bruce et al. 1993, Mari et al. 1993, 1995, 
Poulos et al. 1994, Chang et al. 1996, Durand et al. 1996), and the purpose of this work was to construct specific TS genomic probes to be used as diagnostic reagents and for further TS investigations.

\section{MATERIAL AND METHODS}

Virus strains and infected shrimps. The TSV used for RNA extraction, cDNA synthesis and cloning was purified from TS infected Penaeus vannamei from Hawaii (Hi TSV), collected in 1994 and stored at $-70^{\circ} \mathrm{C}$. The purification was done as described by Bonami et al. (1997).

To test the constructed probes and their specificity, we used another source of TSV, isolated from infected Penaeus vannamei from Ecuador (Ec-TSV), as well as the other shrimp viruses, Infectious Hypodermal and Hematopoietic Necrosis Virus (IHHNV) (Lightner et al. 1983, Bonami et al. 1990) from infected P. stylirostris or $P$. vannamei, and Hepatopancreatic Parvovirus (HPV) (Lightner \& Redman 1985, Bonami et al. 1995) from infected $P$. chinensis. Crude homogenates $(1 \mathrm{~g}$ tissue in $10 \mathrm{ml}$ buffer) of these shrimps were prepared in TN buffer $(0.02 \mathrm{M}$ Tris-HCl, $0.4 \mathrm{M} \mathrm{NaCl}, \mathrm{pH} 7.4)$ for testing in dot blot hybridization assays, and paraffinembedded histological sections of infected shrimp from the same sources were also used for the in situ hybridization assays

RNA extraction. As previously described by Bonami et al. (1997), the RNA was extracted with phenol/ chloroform after proteinase $\mathrm{K}$ and sarkosyl treatments of the purified virus suspension. The RNA was precipitated with absolute ethanol and stored in ethanol at $-70^{\circ} \mathrm{C}$ until use to prevent degradation.

To avoid RNase contamination, all the steps concerning RNA experiments (extraction, cDNA synthesis, electrophoresis, northern blots and dot blots) were done in RNase-free conditions including DEPC (diethylpyrocarbonate) treatment of the buffers and glassware (Sambrook et al. 1989).

cDNA synthesis. Viral RNA stored in ethanol was pelleted, washed with $70 \%$ ethanol, and air dried before being resuspended in an appropriate volume of DEPC-treated distilled water. The transcription of the TS-RNA genome into CDNA was performed using the cDNA Synthesis Kit (Boehringer Mannheim) using random primers as primer for the AMV (Avian Myeloblastosis Virus) reverse transcriptase.

The TSV cDNA obtained was extracted in phenol/ chloroform and precipitated twice with ethanol. Finally, it was resuspended in $0.1 \times \mathrm{TE}$ buffer $(1 \times \mathrm{TE}$ : $10 \mathrm{mM}$ Tris- $\mathrm{HCl}, 1 \mathrm{mM}$ EDTA, $\mathrm{pH}$ 8).

Cloning. The synthesized blunt-ended TSV CDNA was ligated with T4 DNA ligase (Boehringer Mann- heim) at the dephosphorylated SmaI site of both the pUC 18 and the pBluescript II KS-vectors. Transformation was done according to the standard method (Maniatis et al. 1982) using competent Escherichia coli DH5- $\alpha$ cells.

Plasmids were purified using alkaline lysis minipreps (Maniatis et al. 1982) or INSTA minipreps (5 prime-3 prime, Inc.). The extracted plasmids were analyzed by agarose gel electrophoresis and those of interest were digested with the following restriction enzymes: AccI, ApaI, BamHI, ClaI, EcoRI, EcoRV, HincII, HindIII, KpnI, PstI, Sacl, Xbal and XhoI (Boehringer Mannheim).

Gel electrophoresis. Agarose gel electrophoresis (0.8 to $1.2 \%$ ) was performed in $0.5 \times$ TBE (Tris-BorateEDTA) buffer (Sambrook et al. 1989) containing ethidium bromide $\left(0.5 \mu \mathrm{g} \mathrm{ml}^{-1}\right)$ and visualized under UV light. DNA bands of interest were excised from the gel and the DNA was recovered using the Geneclean II Kit (Bio 101, Inc.). For TS-RNA electrophoresis, denaturing formaldehyde gels were used (Sambrook et al. 1989)

Labelling and hybridization. Selected DNA inserts were labelled with digoxigenin DIG-11 dUTP by random primed reaction according to the manufacturers instructions (Genius I kit, Boehringer Mannheim) Likewise, we used the hybridization protocols suggested by the manufacturer (Boehringer Mannheim Genius system user's guide for membrane hybridization, version 3.0). For DNA/DNA hybridization, $10 \mathrm{ng}$ of labelled probe per $\mathrm{ml}$ of standard hybridization buffer [ $(5 \times \mathrm{SSC}$ (saline sodium citrate), $1 \%$ blocking reagent $0.1 \%$ sarkosyl, $0.2 \%$ SDS (sodium dodecyl sulphate)] was used and the hybridization temperature set a $68^{\circ} \mathrm{C}$. The DNA/RNA hybridizations were performed at $42^{\circ} \mathrm{C}$ in high SDS buffer $(5 \times \mathrm{SSC}, 2 \%$ blocking reagent, $50 \mathrm{mM}$ sodium phosphate $\mathrm{pH} 7,0.1 \%$ sarkosyl, $7 \%$ SDS, $50 \%$ formamide) containing 15 to $30 \mathrm{ng}$ $\mathrm{ml}^{-1}$ of labelled probe. Colorimetric detection of the anti-DIG Fab fragment (alkaline phosphatase conjugate) with NBT (Nitroblue tetrazolium) and X-phosphate (5,bromo-4, chloro-3,indolyl phosphate) was done in the maleic acid buffer system recommended by the manufacturer (Boehringer Mannheim)

For in situ hybridization, histological sections of 4 to $5 \mu \mathrm{m}$ thickness were prepared from Davidson's fixed and paraffin-embedded shrimp tissues (Bell \& Lightner 1988), and these were treated according to the technique described by Terenghi \& Polak (1994) with minor modifications: triethanolamide and acetic anhydride treatments were omitted and the amount of labelled probe was reduced to between 25 and $50 \mathrm{ng} \mathrm{ml}^{-1}$.

Northern gel blotting and dot blots. The DNA dot blots were done as suggested in the application manual of Boehringer Mannheim. The technique described 
by Hodge (1994a) was used to perform RNA gel blots (northern blotting). The RNA dot blots were processed essentially according to the procedure described by Hodge (1994b), but due to the diversity of RNA samples (extracted RNA, purified virions, shrimp tissue homogenates), other dilution buffer and denaturation buffer were tested prior to their immobilization on the membrane:

(1) RNA dilution buffer (DEPC-treated $\mathrm{H}_{2} \mathrm{O}, 20 \times \mathrm{SSC}$, formaldehyde: $5: 3: 2$, respectively) was used according to the manufacturer's (Boehringer Mannheim) directions, either with 10 min incubation at $65^{\circ} \mathrm{C}$, or with a 30 min pre-digestion of the sample with proteinase $\mathrm{K}$ (50 $\mu \mathrm{g} \mathrm{m}^{-1}$, final concentration) at $37^{\circ} \mathrm{C}$.

(2) In some experiments, the method of Hodge (1994b) was modified, either by not diluting the denatured sample in $20 \times \mathrm{SSC}$, or by replacing the RNA incubation solution [657 $\mu$ l formamide, $210 \mu]$ formaldehyde, $133 \mu \mathrm{l} 10 \times$ MOPS [3-(N-morpholino) propanesulfonic acid] with an RNA denaturing solution (500 $\mu$ l formamide, $162 \mu$ formaldehyde, $100 \mu \mathrm{l} 10$ $\times$ MOPS) described in Ausubel et al. (1994) for RNA slot blots. To compare the different denaturation methods, the same serial dilution $(1 / 4,1 / 16,1 / 256,1 / 1024)$ was used for each sample. All the nucleic acid blots were performed on positively charged nylon membranes (Boehringer Mannheim).

\section{RESULTS}

\section{The cDNA libraries}

The efficiency of the 3 libraries constructed 11 in pUC 18 vector and 2 in pBluescript) was very low. For the 3 libraries, a total of 858 transformed clones was obtained, in which only $149(17 \%$ of the 'positive' clones) were found to possess a plasmid with an insert size between 200 and 1500 base pairs (bp). Clones with an insert size smaller than $150 \mathrm{bp}$ were not investigated.

The majority ( $87.5 \%$ ) of these 149 clones, possessing a small insert (size ranging from 200 to $500 \mathrm{bp}$ ), were not characterized. Ten of the 12 plasmids with an insert size larger than $750 \mathrm{bp}$ were characterized by restriction enzyme digestion (AccI, ApaI, BamHI, ClaI, EcoRI, EcoRV, HincII, HindIII, KpnI, PstI, SacI, XbaI and $X$ hol), allowing us to construct their restriction maps (Fig. 1). The remaining 2 plasmids, pL5 and pE31, with inserts of $1100 \mathrm{bp}$ and $750 \mathrm{bp}$ respectively, could not be digested with the 13 restriction enzymes listed above.

The pP15 plasmid was the largest with an insert size of 1500 to $1550 \mathrm{bp}$. It shows homologies (but in the reverse orientation) with the restriction map of the

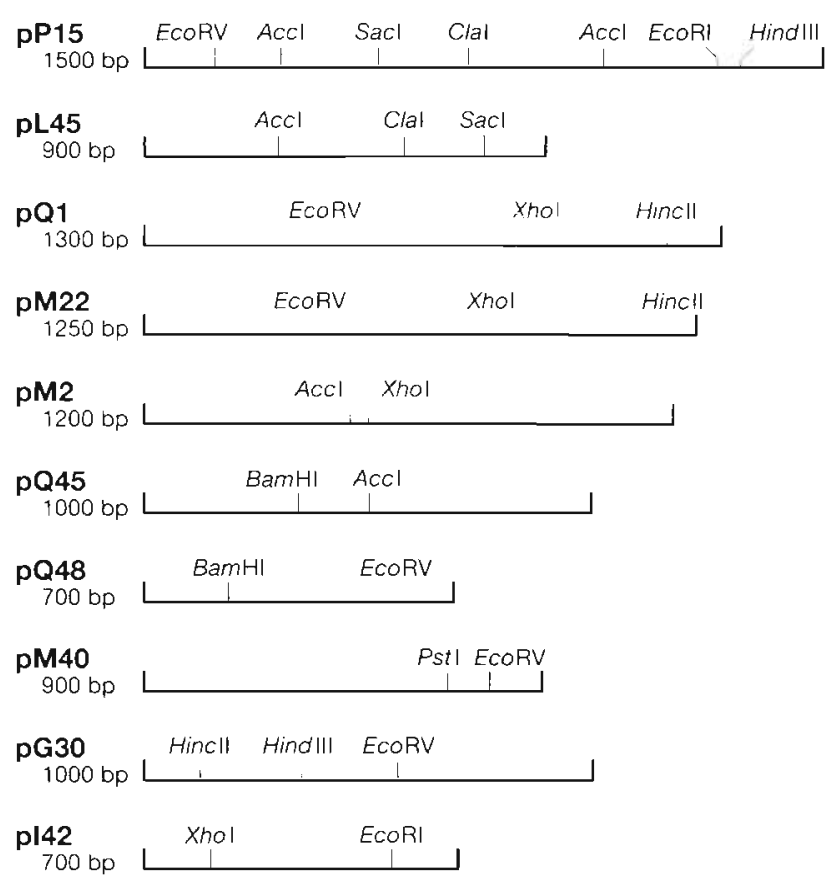

Fig. 1 Insert restriction maps of the recombinant plasmids. Inserts of plasmids pL5 and pE31 are not shown due to the absence of restriction sites for the enzymes used

insert of the pL45 plasmid (900 bp). The inserts in the pQ1 (1300 bp) and pM22 (1250 bp) have the same restriction map. No other such overlaps or restriction map homologies were noticeable for the other characterized plasmids. The pP15 and pQ1 inserts were selected to be labelled and used as probes.

\section{Probe labelling and hybridization assays}

For the pQ1 plasmid, the full insert was obtained by double digestion ECoRI/XbaI, whereas a single HindIII digestion was used with the pP15 plasmid. After separation on agarose gel and excision, the inserts were recovered using the Geneclean II Kit. They were digoxigenin labelled using the Genius I Kit and the corresponding probes were named P15 and Q1.

Attempts for cross-hybridization between pP15 and pQ1 inserts were unsuccessful, suggesting the absence of common sequences and indicating that they correspond to 2 different fragments of the TSV genome.

The specificity of the 2 probes (P15 and Q1) was tested separately after northern transfer following formaldehyde gel electrophoresis of 3 different samples of extracted TSV RNA. Two RNA samples were extracted from a suspension of purified TSV corresponding to 2 different purification experiments carried out on TSV-infected Penaeus vannamei from Ecuador (Ec1 and Ec2 TSV-RNA). The third RNA 
sample used originated from a TSV purification from Hawaiian-reared $P$. vannamei (Hi TSV-RNA). With the 2 probes, identical strong positive reactions of the DNA/RNA hybridizations were obtained with the 3 samples of Hawaiian- and Ecuadorian-derived TSV RNA. (Fig. 2).

Corresponding TSV CDNA, purified HPV and IHHNV, and homogenates of HPV- and IHHNVinfected shrimps were used in dot blots for DNA/DNA hybridizations and probed with the 2 TSV probes (P15 and Q1). The corresponding TSV CDNA showed a strong reaction with the 2 probes, whereas no hybridization occurred with purified HPV or IHHNV or with the IHHNV- and HPV-infected shrimp tissue homogenates (not shown)

Dot blots for DNA/RNA hybridization, performed on extracted TSV RNA, purified virus suspension and homogenates of TS-infected shrimp tissues, were prepared in duplicate to test separately the P15 and Q1 probes. Moreover, different denaturation methods were employed and different amounts of labelled probes $\left(15,20,25\right.$ and $\left.30 \mathrm{ng} \mathrm{ml}^{-1}\right)$ were used. With all denaturation techniques used, a hybridization signal was detected.

For the viral RNA, the best results and sensitivity were obtained using the RNA dilution buffer (Figs. 3 \& 4) and conversely a weaker hybridization reaction was obtained for the homogenized tissues. With the RNA dilution buffer, a good signal was also noted with the purified virus, but the reaction was a little stronger with an incubation at $65^{\circ} \mathrm{C}$. Pre-digestion with proteinase $\mathrm{K}$ did not enhance the signal (Fig. 4). Using the same method, no substantial increase in the hybridization signal was obtained for the homogenates of TSinfected tissues.

The TSV and homogenates of TS-infected tissues treated either with the RNA incubation solution (Hodge 1994b) or with denaturing solution (Ausubel et al. 1994) did not exhibit a significant difference (Fig. 4).
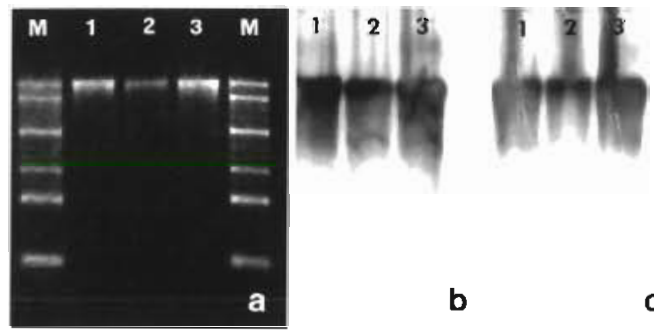

Fig. 2. (a) Denaturing formaldehyde agarose gel electrophoresis of extracted TSV-RNA. The corresponding northern transfer blots were done using a 1:10 dilution of the RNA samples of the electrophoresis. Blot (b) is hybridized with the P15 probe and blot (c) with the Q1 probe. Lane 1: Hi TSVRNA; lane 2: Ec1 TSV-RNA; lane 3: Ec2 TSV-RNA: M: 0.24 to $9.5 \mathrm{~kb}$ ssRNA ladder (Gibco BRL)

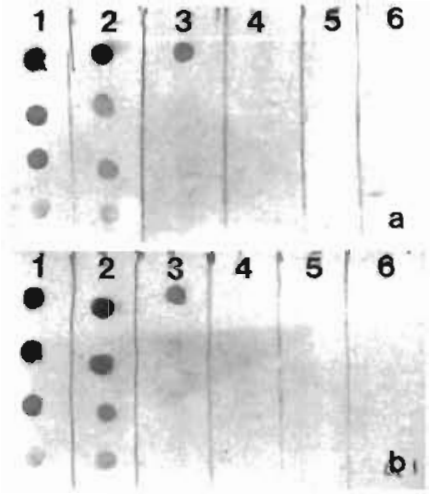

Fig. 3. Dot blot hybridization assays on different TS-derived material and on 2 DNA shrimp viruses. An identical result is obtained with (a) the P15 and (b) the Q1 probes. Lane 1: TSVRNA (using RNA dilution buffer); lane 2: purified TS virus (using RNA incubation solution); lane 3: semi-purified TSV (using RNA incubation buffer); lane 4: negative control; lanes 5 and 6: purified IHHNV and HPV (both shrimp parvoviruses, denatured by boiling). Rows represent serial dilutions $(1 / 4$, $1 / 16,1 / 256,1 / 1024)$ of each sample

Without the $20 \times \mathrm{SSC}$ step, the difference between these 2 treatments was very small. In light of this observation and due to the fact the technique is shorter and easier to use, we chose to omit the $20 \times$ SSC step, thus modifying the procedure of Hodge (1994b), for our further investigations. Using the DNA/RNA hybridization method, IHHNV and HPV viruses were tested. No non-specific reaction was obtained by this technique (Fig. 3)

The specificity of the P15 and Q1 probes against homogenates of non-infected shrimp tissues and

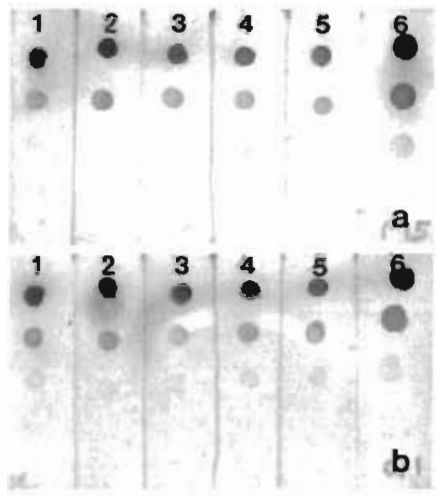

Fig. 4. Comparison of different denaturation methods on purified TSV using dot blot hybridization. Lane 1: RNA dilution buffer; lane 2: RNA dilution buffer with an incubation at $65^{\circ} \mathrm{C}$ lane 3: RNA dilution buffer with a pre-incubation with proteinase $\mathrm{K}$; lane 4: RNA denaturing solution; lane 5: RNA incubation solution without the $20 \times$ SSC step; lane 6 : RNA incubation solution (Hodge 1994b). The dot was hybridized (a) with the P15 probe and (b) with the Q1 probe. Rows represent serial dilutions $(1 / 4,1 / 16,1 / 256,1 / 1024)$ of each sample 
IHHNV-infected shrimp was tested with the above method (without the $20 \times \mathrm{SSC}$ step). Using freshly prepared tissue homogenates, no reaction was noticeable. However, a very weak hybridization signal, at the limit of detection for the first dilution blot $(1 / 4)$, was noted in the case of old frozen homogenates. This reaction, obtained even for healthy or for IHHNVinfected tissues, was interpreted as non-specific, and it was sufficiently weak so as not to interfere with the interpretation of a true positive hybridization, particularly if higher dilution dots showed a hybridization signal (not shown).

The hybridizations carried out using $20 \mathrm{ng} \mathrm{ml}^{-\mathrm{i}}$ of probe (either P15 or Q1) gave good reactions with no background against purified virus and TSV tissue homogenates. With higher probe concentration, the reaction was similar, but a background was noticeable. Conversely, the use of $15 \mathrm{ng} \mathrm{ml}^{-1}$ gave a less intense hybridization signal. Results were identical for the 2 probes tested. The use of an equimolar mix of the 2 probes $\left(10 \mathrm{ng} \mathrm{ml}^{-1}\right.$ of each P15 and Q1), compared to a similar amount (20 $\mathrm{g} \mathrm{m}^{-1}$ ) for each used separately, gave an identical, to slightly more intense, hybridization signal.

\section{In situ hybridization}

Paraffin-embedded sections of either healthy or TSV-infected Penaeus vannamei were hybridized with an equimolar mix of the P15 and Q1 probes. No reaction was found in uninfected control shrimp tissues. In the TSinfected shrimp sections, a strong positive hybridization signal was detected in the cytoplasm of the target tissues and at the level of the lesions described in histological diagnosis of the disease (Fig. 5).

\section{DISCUSSION AND CONCLUSION}

The construction of these cDNA libraries constitutes the first attempt to clone an RNA shrimp virus. The choice of random primers for the cDNA first strand syn-

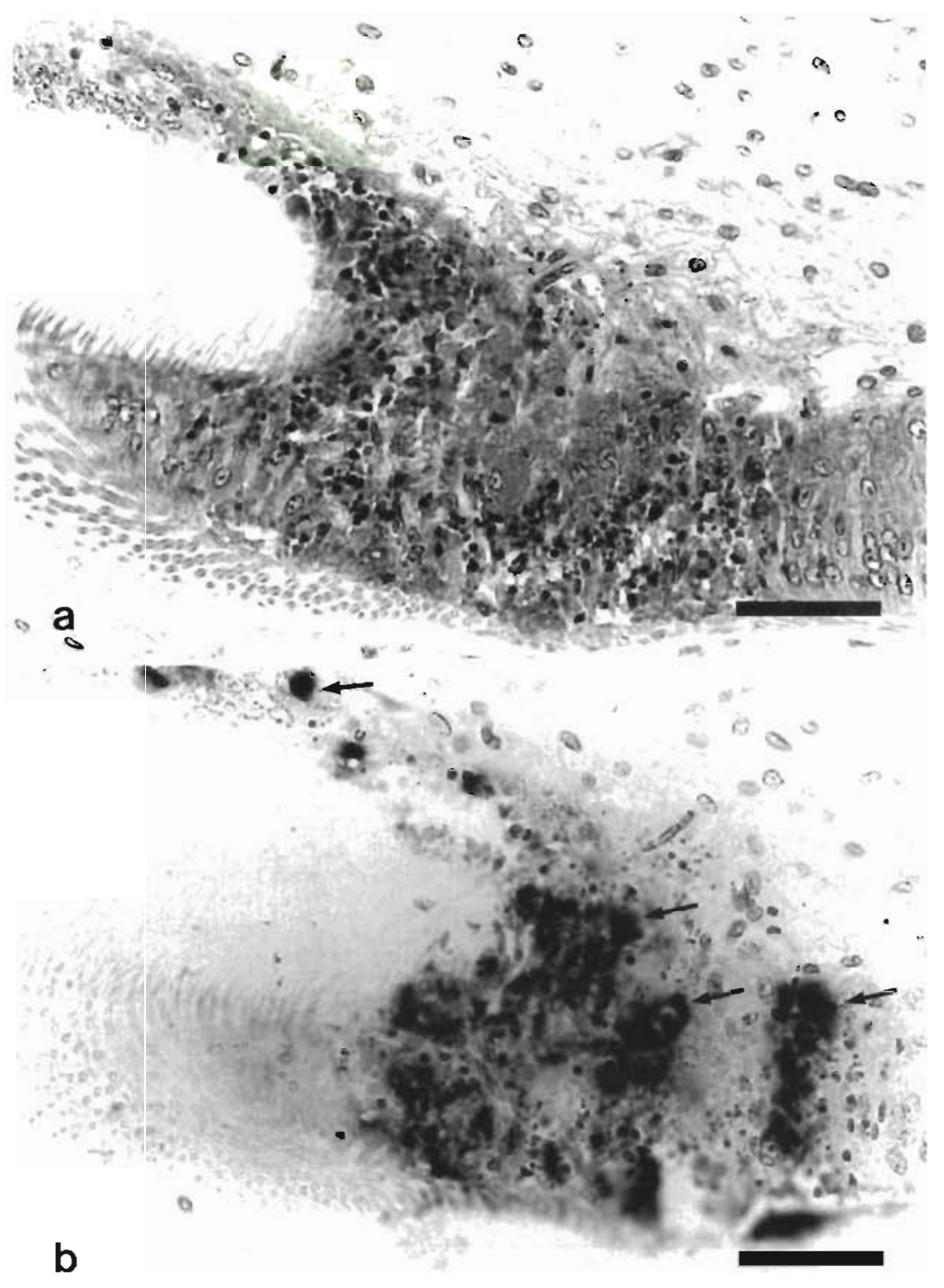

Fig. 5. Penaeus vannamej. Parallel histological sectıons of TSV lesions in cuticular epithelium of the stomach of juvenile shrimp experimentally infected. (a) hematoxylin and eosin staining. (b) In situ hybridization with an equimolar mix of P15 and Q1 probes, counter-stained with Bismarck brown. The infected areas (arrows) reacted strongly with the probes, whereas areas with normal cuticular epithelial cells do not show any hybridization reaction. Scale bars $=$ $50 \mu \mathrm{m}$

thesis was determined by the fact that a poly-adenylated 3 '-end was not known to exist when this study was started. Also, this strategy was chosen to obtain efficient synthesis of full length dsDNA. The cDNA was directly ligated to the plasmid for construction of the libraries and the length distribution of the cDNA transcripts was not checked. The acquisition of numerous recombinant plasmids with a small insert size $(87.5 \%)$ can be explained by the presence of low molecular weight transcripts which were not removed by 
size fractionation. The largest insert, which is only $1500 \mathrm{bp}$, represents $16 \%$ of the total RNA genome; this could reflect a non-efficient transcription of the RNA into cDNA. The construction of other CDNA libraries using an oligo-dT primed method for the CDNA should be considered for future studies on the TSV genome.

The 12 characterized inserts presented relatively few restriction sites for the 13 enzymes used, and some, like pE31 and pL5, were not digested by any of these enzymes. Based on the restriction sites found, it was not possible to locate any overlaps in order to construct a part of the TSV genome restriction map. The full RNA genome is estimated to be $9 \mathrm{~kb}$ (Bonami et al. 1997). The total size of the inserts (excluding pL45 and pM22 because they exhibit homologies with pP15 and $p Q 1$ ) is $9700 \mathrm{bp}$. Hence, we assume that we have cloned a large part of the TSV genome and that we must have overlaps of common sequences between some inserts. The search for possible overlaps is currently in progress via a comparison of sequences of the different inserts and cross-hybridization after Southern transfer.

The 2 probes, P15 and Q1, were obtained using a cDNA derived from the RNA genome of a Hawaiian TSV isolate. These probes do not cross-hybridize and they react with the same level of intensity in the hybridization assays. In northern blot hybridization, they do not distinguish a Hawaiian TSV-RNA from an Ecuadorian TSV isolate, confirming the results of Hasson et al. (1995) and Bonami et al. (1997) on the same etiologic agent from the 2 geographic areas. The investigations on the specificity of the 2 probes against other shrimp viruses (IHHNV and HPV), on tissues of corresponding IHHNV- and HPV-infected shrimps, and on healthy shrimp tissues reveal no hybridization reaction, but, conversely, demonstrated hybridization only with TS-derived material (RNA, TS virus, or TSV-infected tissue). This specificity was confirmed by in situ hybridization. Since only the target cells and tissues described as typical histological lesions for TS disease (Brock et al. 1995, Lightner et al. 1995, Lightner 1996a) react with the probes, this method has a higher level of sensitivity and better accuracy than that offered by routine H\&E (hematoxylin and eosin) histology. Therefore, based on their specificity, the P15 and Q1 probes can be used for TS diagnosis. Only the level of sensitivity for the DNA/RNA dot blot hybridization for tissue homogenates needs to be improved. The different denaturation methods tested on the shrimp homogenates do not demonstrate a noticeable difference in the sensitivity of detection. One limitation of the described procedure is a very weak, non-specific response obtained with some frozen homogenates that may be interpreted, in a routine diagnosis, as a very low level of TSV infection. On the other hand, this method gives a very good correlation between the presence of TS and the hybridization signal, even in low level infoctions, when the homogenized tissue is freshly prepared. Other strategies, based on a total RNA extraction from tissues, are being considered as methods to be used for a more sensitive diagnosis.

Acknowledgements. Support for the work reported here came from the Gulf Coast Research Laboratory Consortium Marine Shrimp Farming Program, CSREES, U.S. Dept of Agriculture (grant no. 95-38808-1424), the National Sea Grant Program, U.S. Dept of Commerce, NOAA (grant no. NA56RG0617), the U.S. Dept of Commerce, NOAA, Saltonstall-Kennedy Program (grant no. NA56FD0621), and the National Fisheries Institute.

\section{LITERATURE CITED}

Ausubel FM, Brent R, Kingston RE, Moore DD, Seidman JG, Smith JA, Struhl K (1994) Current protocols in molecular biology. John Wiley \& Sons, Inc, New York

Bell TA, Lightner DV (1988) A handbook of normal penaeid shrimp histology. World Aquaculture Society, Baton Rouge, LA

Bonami JR, Hasson KW, Mari J, Poulos BT, Lightner DV (1997) Taura syndrome of marine penaeid shrimp: characterization of the viral agent. J Gen Virol 78:313-319

Bonami JR, Mari J, Poulos BT, Lightner DV (1995) Characterization of hepatopancreatic parvo-like virus, a second unusual parvovirus pathogenic for penaeid shrimps. J Gen Virol 76:813-817

Bonami JR, Trumper B, Mari J, Brehelin M, Lightner DV (1990) Purification and characterization of the infectious hypodermal and haematopoietic necrosis virus of penaeid shrimps. J Gen Virol 71:2657-2664

Brock JA, Gose R, Lightner DV, Hasson KW (1995) An overview of Taura syndrome, an important disease of farmed Penaeus vannamei. In: Browdy CL, Hopkins JS (eds) Swimming through troubled water. Proceedings of the special session on shrimp farming. World Aquaculture Society, Baton Rouge, LA, p 84-94

Bruce LD, Redman RM, Lightner DV, Bonami JR (1993) Application of gene probes to detect a penaeid shrimp baculovirus in fixed tissue using in situ hybridization. Dis Aquat Org 17:215-221

Chang PS, Lo CF, Wang YC, Kou GH (1996) Identification of white spot syndrome associated virus (WSBV) target organs in the shrimp Penaeus monodon by in situ hybridization. Dis Aquat Org 27:131-139

Durand S, Lightner DV, Nunan LM, Redman RM, Mari J, Bonami JR (1996) Application of gene probes as diagnostic tools for white spot baculovirus (WSBV) of penaeid shrimp. Dis Aquat Org 27:59-66

Hasson KW, Lightner DV, Poulos BT, Redman RM, White BL, Brock JA, Bonami JR (1995) Taura syndrome in Penaeus vannamei: demonstration of a viral etiology. Dis Aquat Org 23:115-126

Hodge R (1994a) Preparation of RNA gel blots. In: Isaac PG (ed) Methods in molecular biology, Vol 28. Protocols for nucleic acid analysis by nonradioactive probes. Humana Press Inc, Totawa, NJ, p 49-54

Hodge R (1994b) Preparation of RNA dot blots. In: Isaac PG (ed) Methods in molecular biology, Vol 28. Protocols for 
nucleic acid analysis by nonradioactive probes. Humana Press Inc, Totawa, NJ, p 55-57

Jimenez R (1992) Sindrome de Taura (Resumen). Aquacultura Ecuador, Guayaquil 1:1-16

Lightner DV (1996a) The penaeid shrmp viruses IHHNV and TSV: epizootiology, production impacts and role of international trade in their distribution in the Americas. Rev Sci Tech OIE (Offi Int Epizoot) 15(2):579-601

Lightner DV (1996b) A handbook of shrimp pathology and diagnostic procedures for diseases of cultured penaeid shrimp. World Aquaculture Society, Baton Rouge, LA

Lightner DV, Jones LS, Ware GW (1994) Proceedings of the Taura Syndrome Workshop: executive summary, submitted reports, and transcribed notes. Jan 21-22, 1994, Univ Arizona, Tucson

Lightner DV, Redman RM (1985) A parvo-like virus disease of penaeid shrimp. J Invertebr Pathol 45:47-53

Lightner DV, Redman RM, Bell TA (1983) Infectious hypodermal and haematopoietic necrosis, a newly recognized virus disease of penaeid shrimp. J Invertebr Pathol 42 : $62-70$

Lightner DV, Redman RM, Hasson KW, Pantoja CR (1995) Taura syndrome in Penaeus vannamei (Crustacea: Decapoda): gross signs, histopathology and ultrastucture. Dis Aquat Org 21:53-59

Maniatis T, Fritsch EF, Sambrook J (1982) Molecular cloning:

Editorial responsibility: Larry Vaughan,

Dublin, Ireland a laboratory manual. Cold Spring Harbor Laboratory, Cold Spring Harbor, NY

Mari J, Bonami JR, Lightner DV (1993) Partial cloning of the genome of infectious hypodermal and haematopoietic necrosis virus, an unusual parvovirus pathogenic for penaeid shrimps; diagnosis of the disease using a specific probe. J Gen Virol 74:2637-2643

Mari J, Lightner DV, Poulos BT, Bonami JR (1995) Partial cloning of the genome of an unusual shrimp parvovirus (HPV); use of gene probes in disease diagnosis. Dis Aquat Org 22:129-134

Poulos BT, Mari J, Bonami JR, Redman RM, Lightner DV (1994) Use of non-radioactive labeled DNA labeled probes for the detection of a baculovirus from Penaeus monodon (PmSNPV=MBV) by in situ hybridization on fixed tissue. J Virol Meth 49:187-194

Sambrook J, Fritsch EF, Maniatis T (1989) Molecular cloning A laboratory manual, 2nd edn, Vol 1-3. Cold Spring Harbor Laboratory, Cold Spring Harbor, NY

Terenghi G, Polak JM (1994) Detecting mRNA in tissue sections with digoxigenin-labeled probes. In: Isaac PG (ed) Methods in molecular biology, Vol 28. Protocols for nucleic acid analysis by nonradioactive probes. Humana Press Inc, Totawa, NJ, p 193-199

Wigglesworth J (1994) 'Taura syndrome' hits Ecuador farms Fish Farmer 17(3):30-31

Submitted: November 27, 1997; Accepted: March 3, 1998 Proofs received from author(s): May 4, 1998 